\title{
The clinical significance of tumor infiltrating lymphoctyes in breast cancer: does subtype matter?
}

\author{
Jonathan Krell, Adam E Frampton and Justin Stebbing
}

\begin{abstract}
Tumor infiltrating lymphocytes (TILs) are commonly detected in breast tumors but their bearing on disease outcome is uncertain. The importance of TILs appears to be subtype-specific and varies depending on the histologic characteristics of the tumor. As our understanding of tumorigenesis is increasing the relevance of immunobiology will become apparent.
\end{abstract}

Keywords: Tumor infiltrating lymphocytes, Cancer, Immunobiology

\section{Background}

Breast cancer comprises many different subtypes characterized by distinguishing factors such as cell type of origin, grade and molecular specificities such as Ki-67 levels and receptor status. In recent years further molecular characteristics such as specific protein and miRNA expression levels have been associated with tumor phenotype $[1,2]$, and it appears that multiple factors determine prognosis in this disease. Although a greater understanding of cancer cell biology is imperative to improving treatment, it has been shown that variability in the tumor microenvironment can also impact on outcome. The past 30 years have accumulated considerable evidence that tumors can elicit a significant immune response, and the body's normal defence mechanisms can play a key role in promoting or preventing carcinogenesis and tumor spread [3]. Tumors are commonly infiltrated by lymphocytes (TILs) and their number and subtype are considered to reflect the host immune response to malignancy [4]. The concept of cancer immunobiology appears to be an important one and the possible role of TILs in determining outcome in breast and other cancers needs further evaluation.

\footnotetext{
* Correspondence: j.krell@imperial.ac.uk

Department of Surgery and Cancer, Imperial College, Hammersmith Hospital,
} Du Cane Road, London W12 ONN, UK

\section{Biomed Central}

(c) 2012 Krell et al; licensee BioMed Central Ltd. This is an Open Access article distributed under the terms of the Creative Commons Attribution License (http://creativecommons.org/licenses/by/2.0), which permits unrestricted use, distribution, and reproduction in any medium, provided the original work is properly cited.

\section{Main text}

Cytotoxic $\mathrm{CD}^{+}$and $\mathrm{CD} 4^{+} \mathrm{Th} 1 \mathrm{~T}$ cells function as the major anti-tumor lymphocytes predominantly through the production of interferon-gamma (IFN- $\gamma$ ), whereas interleukin-6 (IL-6), tumor-necrosis factor (TNF) and IL-23 produced by tumor-associated macrophages (TAM) or myeloid-derived suppressive cells (MDSC) are believed to promote tumor formation and growth. The roles played by TILs such as $\mathrm{CD} 4^{+} \mathrm{CD} 25^{+}$Foxp $3^{+}$TILs (Tregs) and Th17 cells remains less clear but they appear to suppress the activity of effector cells including CD4+ and CD8+ cytotoxic T cells, natural killer cells, natural killer $\mathrm{T}$ cells, and $\mathrm{B}$ cells $[5,6]$. This activity may promote the survival of cancer cells by affording protection from both the innate and adaptive immune systems. Several studies have shown that tumor infiltration by effector T lymphocytes is associated with favorable prognosis $[7,8]$, but that higher numbers of Tregs are associated with progression in a variety of malignancies $[9,10]$.

The clinical significance of TILs in breast cancer remains controversial and lymphocyte location and subtype appears to determine outcome. High CD4+ and CD8+ lymphocytic infiltration has been associated with positive lymph node status as well as worse overall survival [11], but higher relative levels of CD8+ TILs in ER negative breast cancer correlates with a better prognosis [12]. Infiltration by Tregs correlates with tumor invasiveness and was shown to represent an independent 
unfavorable prognostic factor, especially in lymph node positive breast cancer [13]. TIL levels have also been associated with response to breast cancer therapy. Treg levels were significantly reduced during treatment with trastuzumab whilst Th17 frequencies were concomitantly increased [14] and TIL counts have been shown to represent an independent predictor of response to neo-adjuvant paclitaxel [15].

The paper by Droeser and coworkers in this addition of BMC cancer addresses the role of TILs in breast cancer and particularly focuses on the differential lymphocyte infiltration between histological subtypes. Furthermore, they utilise an extensive clinical follow-up database to correlate TIL number in different tumor compartments with clinico-pathological features and outcome data. The study is significant in a number of ways: Firstly, despite being a retrospective study the sample size is large and certainly sufficient for the purpose of the analysis. Secondly it addresses issues that have not previously been reported such as T-cell infiltration in different histological subtypes and the occurrence of IL-17+ lymphocytes in breast cancer tissue. They used standard immunohistochemical techniques to stain for TILs in a tissue microarray that included 894 ductal and 164 lobular breast cancers and correlated lymphocyte counts with clinico-pathological parameters and survival. The major findings were that ductal and lobular breast cancers appear to be infiltrated by different lymphocyte subpopulations and that in ductal cancers increased CD4+ and FOXP3+ lymphocyte infiltration was linked to more aggressive histological features (such as higher grade and ER-negative status) but in lobular carcinomas lymphocyte infiltration was not linked to any clinico-pathological parameters. Interestingly, although no prognostic relevance could be attributed to absolute TIL number in either histological subtype, a FOXP3+ to CD4+ ratio of greater than one in ductal carcinoma seemed to represent an independent favorable prognostic variable. IL-17 lymphocyte numbers were low in both histological subtypes and no significant difference between TILs was described between tumor or stroma tissue.

\section{Discussion}

So what is the true clinical relevance of the current study by Droeser et al.? It provides further evidence that evaluating Treg tumor infiltration may be a useful adjunct to current methods used for staging breast cancer and may serve as a reliable prognostic biomarker. However the data suggest that it is the relative infiltration of different Tregs rather than absolute number that is most important in this respect. Furthermore, similar future studies in the metastatic setting may demonstrate a role for TILs in predicting the behavior of advanced tumors. The study also suggests a possible role for TILs as diagnostic biomarkers as there is a clear difference in lymphoctye infiltration between histological subgroups. This finding may also provide valuable information as to how variability in immunogenicity is associated with different tumors or tumor growth patterns. A greater understanding of the function of TILs within a tumor might also aid in identifying those patients most likely to benefit from immunomodulatory therapies in breast cancer, a strategy that has been used with varying success in other tumor types such as melanoma [16] and renal cell carcinoma [17].

\section{Conclusion}

In an era when standard prognostic, predictive and diagnostic parameters are ever changing and the use of extended molecular fingerprint analyses are increasing, we are continually looking for techniques to further our understanding of tumor biology and improve patient outcome. Although further work is clearly required to fully establish the importance and potential role of TILs in breast and other malignancies, it seems clear that a thorough assessment of the immunobiological status of tumors will go someway to achieving these goals. The relevance of tumor lymphocyte infiltration cannot be ignored but needs to be properly evaluated in larger prospective studies which must encompass the parameters set out in this and previous studies.

\section{Authors' contributions}

JK prepared the main text, discussion and conclusion. AEF prepared the background and edited the manuscript. JS supervised the writing of the manuscript and edited the draft.

\section{Competing interests}

The authors declare that they have no competing interests.

Received: 27 February 2012 Accepted: 3 April 2012

Published: 3 April 2012

\section{References}

1. Caprioli RM: Deciphering protein molecular signatures in cancer tissues to aid in diagnosis, prognosis, and therapy. Cancer Res 2005, 65(23):10642-10645.

2. Calin $G A$, Croce $C M$ : MicroRNA signatures in human cancers. Nature reviews Cancer 2006, 6(11):857-866.

3. Pandolfi F, Cianci R, Pagliari D, Casciano F, Bagala C, Astone A, Landolfi R, Barone C: The Immune Response to Tumors as a Tool toward Immunotherapy. Clinical \& developmental immunology 2011, 2011:894704.

4. Mahmoud SM, Paish EC, Powe DG, Macmillan RD, Grainge MJ, Lee AH, Ellis IO, Green AR: Tumor-infiltrating CD8+ lymphocytes predict clinical outcome in breast cancer. J Clin Oncol 2011, 29(15):1949-1955.

5. Trzonkowski P, Szmit E, Mysliwska J, Dobyszuk A, Mysliwski A: CD4 + CD25 $+T$ regulatory cells inhibit cytotoxic activity of $\mathrm{T} C D 8+$ and NK lymphocytes in the direct cell-to-cell interaction. Clin Immunol 2004, 112(3):258-267.

6. Murakami M, Sakamoto A, Bender J, Kappler J, Marrack P: CD25 + CD4+ T cells contribute to the control of memory CD8+ T cells. Proc Natl Acad Sci USA 2002, 99(13):8832-8837.

7. Galon J, Costes A, Sanchez-Cabo F, Kirilovsky A, Mlecnik B, Lagorce-Pages C, Tosolini M, Camus M, Berger A, Wind P, et al: Type, density, and location 
of immune cells within human colorectal tumors predict clinical outcome. Science 2006, 313(5795):1960-1964.

8. Oble DA, Loewe R, Yu P, Mihm MC Jr: Focus on TILs: prognostic significance of tumor infiltrating lymphocytes in human melanoma. Cancer immunity: a journal of the Academy of Cancer Immunology 2009, 9:3.

9. Wolf AM, Wolf D, Steurer M, Gastl G, Gunsilius E, Grubeck-Loebenstein B: Increase of regulatory $T$ cells in the peripheral blood of cancer patients. Clin Cancer Res 2003, 9(2):606-612.

10. Nedergaard BS, Ladekarl M, Thomsen HF, Nyengaard JR, Nielsen K: Low density of $\mathrm{CD} 3+, \mathrm{CD} 4+$ and $\mathrm{CD} 8+$ cells is associated with increased risk of relapse in squamous cell cervical cancer. Br J Cancer 2007, 97(8):1135-1138.

11. Matkowski R, Gisterek I, Halon A, Lacko A, Szewczyk K, Staszek U, Pudelko M, Szynglarewicz B, Szelachowska J, Zolnierek A, et al: The prognostic role of tumor-infiltrating CD4 and CD8 T lymphocytes in breast cancer. Anticancer research 2009, 29(7):2445-2451.

12. Rakha EA, Aleskandarany M, El-Sayed ME, Blamey RW, Elston CW, Ellis IO, Lee AH: The prognostic significance of inflammation and medullary histological type in invasive carcinoma of the breast. Eur J Cancer 2009, 45(10):1780-1787.

13. Merlo A, Casalini P, Carcangiu ML, Malventano C, Triulzi T, Menard S, Tagliabue E, Balsari A: FOXP3 expression and overall survival in breast cancer. J Clin Oncol 2009, 27(11):1746-1752.

14. Horlock C, Stott B, Dyson PJ, Morishita M, Coombes RC, Savage P, Stebbing J: The effects of trastuzumab on the CD4 + CD25 + FoxP3+ and CD4 + IL17A + T-cell axis in patients with breast cancer. Br J Cancer 2009, 100(7):1061-1067.

15. Denkert C, Loibl S, Noske A, Roller M, Muller BM, Komor M, Budczies J, Darb-Esfahani S, Kronenwett R, Hanusch C, et al: Tumor-associated lymphocytes as an independent predictor of response to neoadjuvant chemotherapy in breast cancer. $J$ Clin Oncol 2010, 28(1):105-113.

16. Rosenberg SA, Packard BS, Aebersold PM, Solomon D, Topalian SL, Toy ST, Simon P, Lotze MT, Yang JC, Seipp CA, et al: Use of tumor-infiltrating lymphocytes and interleukin-2 in the immunotherapy of patients with metastatic melanoma. A preliminary report. N Engl J Med 1988, 319(25):1676-1680

17. Figlin RA, Thompson JA, Bukowski RM, Vogelzang NJ, Novick AC, Lange P, Steinberg GD, Belldegrun AS: Multicenter, randomized, phase III trial of CD8(+) tumor-infiltrating lymphocytes in combination with recombinant interleukin-2 in metastatic renal cell carcinoma. J Clin Oncol 1999, 17(8):2521-2529

\section{Pre-publication history}

The pre-publication history for this paper can be accessed here: http://www.biomedcentral.com/1471-2407/12/135/prepub

doi:10.1186/1471-2407-12-135

Cite this article as: Krell et al:: The clinical significance of tumor infiltrating lymphoctyes in breast cancer: does subtype matter? BMC Cancer 2012 12:135.

\section{Submit your next manuscript to BioMed Central and take full advantage of:}

- Convenient online submission

- Thorough peer review

- No space constraints or color figure charges

- Immediate publication on acceptance

- Inclusion in PubMed, CAS, Scopus and Google Scholar

- Research which is freely available for redistribution

Submit your manuscript at www.biomedcentral.com/submit
Biomed Central 